\title{
A Photograph of Four Orientalists (Bombay, 1885): Knowledge Production, Religious Identities, and the Negotiation of Invisible Conflicts
}

\author{
Filipa Lowndes Vicente*
}

\begin{abstract}
By analyzing the history of a photograph taken in a Bombay photo studio in 1885 , this article explores notions of the production of knowledge on India and cultural dialogues, encounters, appropriations, and conflicts in colonial British India in the late nineteenth century. The photograph was taken after a Hindu religious ceremony in honour of the Italian Sanskritist Angelo de Gubernatis. Dressed as a Hindu Brahman, he is the only European photographed next to three Indian scholars, but what the image suggests of encounter and hybridity was challenged by the many written texts that reveal the conflicting dialogues that took place before and after the portrait was taken. Several factors were examined in order to decide who should and who should not be in the photograph: religion, cast, and even gender were successively discussed, before the category of "knowledge" became the bond that unified the four men who studied, taught, and wrote on India.
\end{abstract}

En analysant l'histoire d'une photographie prise dans un studio photographique de Bombay en 1885, cet article explore les notions de production du savoir sur l'Inde, de dialogues, rencontres, appropriations et conflits culturels dans le contexte de l'Inde coloniale britannique de la fin du XIX ${ }^{\mathrm{e}}$ siècle. La photographie fut prise à l'issue d'une cérémonie religieuse hindoue en l'honneur du sanskritiste italien Angelo de Gubernatis. Habillé en brahmane hindou, il est le seul Européen photographié aux côtés de trois érudits indiens. L'idée de rencontre et d'hybridité suggérée par l'image est toutefois remise en cause par les nombreux textes écrits révélant les dialogues conflictuels qui eurent lieu avant et après la réalisation du portrait. Un certain nombre de facteurs furent examinés pour décider qui devrait et qui ne devrait pas figurer sur la photographie: la religion, la caste et même le sexe furent successivement discutés avant que la catégorie du «savoir» s'impose comme le lien unificateur des quatre hommes qui étudiaient, enseignaient et écrivaient sur l'Inde.

\section{Keywords}

colonial knowledge, Orientalism, colonial photography, Indian studies, archives

*) Filipa Lowndes Vicente, Institute of Social Sciences, University of Lisbon (ICS-UL), filipa.vicente@ics.ul.pt. 
In October 1885, four men got together in a Bombay studio to have a photograph taken of them dressed as Hindu Brahmans. ${ }^{1}$ The image itself was made to document and celebrate the event that had just taken place in the studio: the Italian professor of Sanskrit Angelo de Gubernatis, the only non-Indian of the four, was the object of a Hindu purification ceremony performed by the man portrayed behind him, the illustrious Pandit Bhagwanlal. The main aim of his Indian journey was to gather Hindu religious objects, visit temples, and meet those in charge of the sacred spaces. This Hindu ceremony, the name of which he did not mention, worked for him mainly as a symbolic transformation process. He wanted to legitimize his contact with sacred India, his principal interest. To be the object of such an honour and to appear in a photograph next to three recognized Indian scholars-José Gerson da Cunha, Shyamaji Krishnavarma, and Bhagwanlal—naturally reinforced Gubernatis's status as the main Italian specialist on India. Interested in increasing the resonance of the event, he made the photograph and the many written descriptions of the ceremony available to various media and publics in India and in Italy.

Through the analysis of the history of a specific photograph, this article will explore various types of cultural dialogues and encounters in the contexts of colonial British India and Italian orientalism during the second half of the nineteenth century. It also confronts us with two geographical spaces that are somewhat outside the scope of most studies on knowledge production in colonial contexts-Florence and Bombay. ${ }^{2}$ The city of Florence and the nation of Italy, which lay outside the world of colonialism until the late nineteenth century, appear as surprisingly rich locales for

\footnotetext{
1) Angelo de Gubernatis (1840 Turin, 1913 Rome) was educated in Berlin, where he studied philology and Sanskrit with Franz Bopp and Albrecht Weber. On his return to Italy, he was appointed professor of Sanskrit at the University of Florence, where he remained until 1891, when he was invited to teach Italian literature and Sanskrit at the University of Rome. In Florence he was active in developing what was called "oriental studies," through the creation of many journals (Rivista Orientale, Bolletino Italiano degli studii orientali, Giornale della Società Asiatica) and the founding of the Indian Museum and Società Asiatica Italiana and the organization of the Fourth International Congress of Orientalists. He was the editor of many biographical dictionaries and published numerous books on Italian literature and Indian studies.

2) F.L. Vicente, Outros orientalismos. A Índia entre Florença e Bombaim 1860-1900 (Lisbon: Imprensa de Ciências Sociais, 2009). This article is based on the work done for this book, which will also be published in Italian and English.
} 
the production of knowledge on India throughout the second half of the century. Bombay, on the other hand, usually more associated with commerce than the more intellectual Calcutta, reveals itself as a city with significant institutions and instruments of knowledge and a multi-religious, multi-ethnic community of scholars.

We did not find the photograph itself but only a reproduction in a newspaper, but there is a wide array of documents and sources that discuss its making and its reception and enable us to argue for the need to combine visual and textual sources in the same historiographical approach. The significance attached to the act of being photographed and the quantity of materials available on the production of one photograph will allow us to make a "thick description" of the photograph as an historical object. ${ }^{3}$ The apparent stability of what was visible - the photograph of an Italian orientalist and three Indian scholars, all dressed in native costume, taken in a Bombay studio-was rendered problematic by the many layers of written dialogues that negotiated the making of the photograph, before it was taken in Bombay, and then discussed its reception, when it was reproduced in Italy.

There were, in fact, two specific moments that generated rich and sometimes conflicting dialogues about the photograph itself: one took place after the publication of the image in Italy, while the other happened before the photograph was taken. On 13 December 1885 the popular Italian weekly newspaper L'Illustrazione Italiana dedicated half a page to a sketch based on the photograph, which had recently arrived from Bombay (Illustration 1$).{ }^{4}$ In travelling from Bombay to Italy to be exhibited in a different national and cultural context and to a wider audience, the photograph necessarily acquired other meanings. The control over these meanings, or the inability to exercise such control, revealed the cultural and identity sensibilities that were at stake and that had already been present in the conflicting dialogues that took place before the actual photograph was made, during negotiations over who should be photographed and who should not, and why.

Through these dialogues, present through personal correspondence and private diaries and related to both the production and the reception of

3) C. Geertz, "Thick Description: Toward an Interpretive Theory of Culture," in The Interpretation of Cultures: Selected Essays, C. Geertz (New York: Basic Books, 1973): 3-30.

4) “De Gubernatis Brahmino," L'Illustrazione Italiana, 12/50 (1885): 378-80. The photograph was apparently sent by Angelo de Gubernatis himself. 


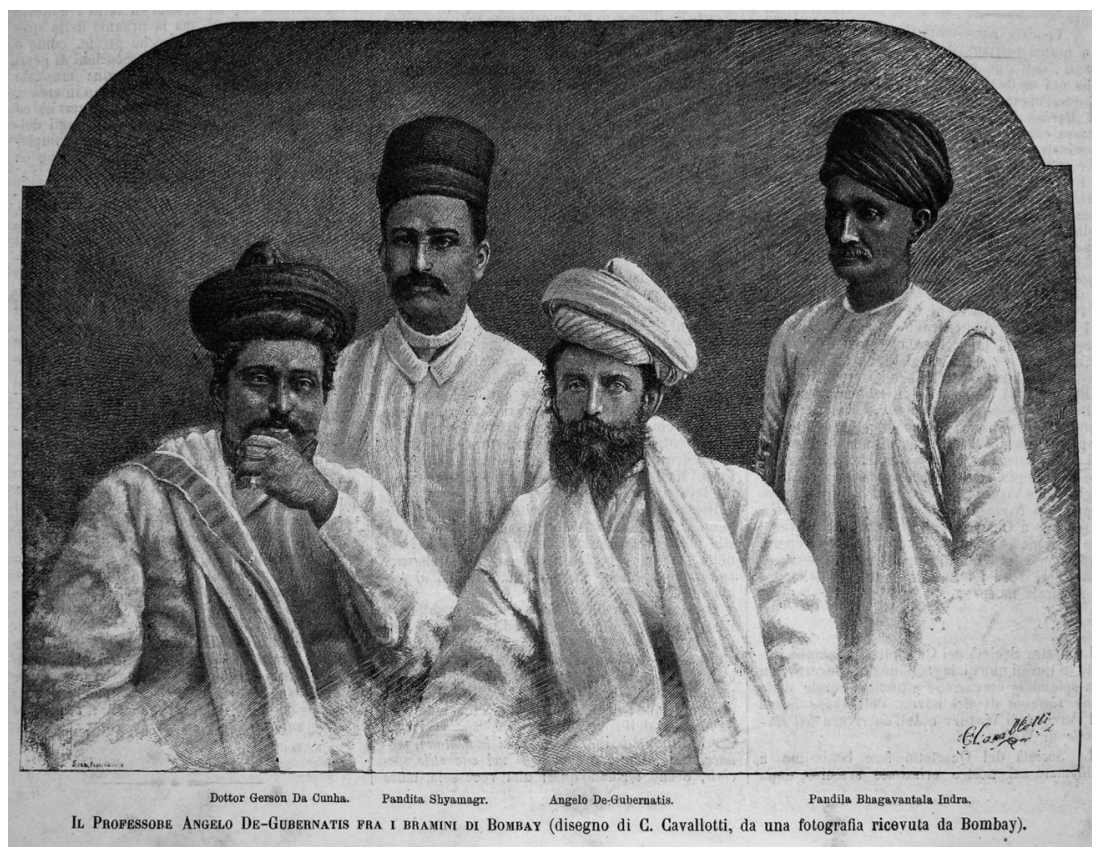

Group portrait with José Gerson da Cunha, Angelo De Gubernatis (seated, from left to right), Shyamaji Krishnavarma and Bhagwanlal (standing, from left to right), 1885. Litography. Drawing made by C. Cavallotti after a photograph taken in a Bombay photographic studio on the 10th October 1885. Published in L'Illustrazione Italiana, $\mathrm{n}^{\circ} 50$ (13 December 1885) with the article "De Gubernatis Brahmino"

the photograph, we will explore notions of cultural, religious, and ethnic identity that go beyond the simplistic division between one European and the three Indians with whom he was photographed, which a superficial approach to the image might suggest. We shall first analyze the circulation of the image and its reproduction and then concentrate on the discussions that negotiated who should and should not be photographed, which resulted in the final agreement that all had to be "learned." After discussing the religious ceremony itself, which culminated in the photograph, we will analyze the histories of the four men portrayed in the photograph and the relationships between them, in the framework of knowledge production, scholarly collaboration, and comparisons between Indian and European knowledges. 


\section{The Circulation and Reproduction of an Indian Photograph}

Having not found the original photograph, we can only analyze the printed sketch based on it that was published in a newspaper, which was thus a reproduction of a reproduction. ${ }^{5}$ But, while the absence of the original photograph can be viewed as a limitation, it can also be interpreted as a historical fact in itself, revealing the reproductive power the image assumed during this period and the increasing speed of this process. A photograph taken in Bombay in October 1885 was transported by sea to Milan. There it was reproduced as a drawing by an employee of a newspaper, which then printed it and revealed it, in December (two months after it was taken), to the gaze of the Italian readership of the popular L'Illustrazione Italiana. The same issue in which the photograph was reproduced had pages full of images of the Eritrean cities of Massawa and of Assab, where Italy had established its first African colonies, in 1885.

According to the caption under the illustration, the image was of "Professor Angelo de Gubernatis with the Brahmans of Bombay." The three Brahmans-Gerson da Cunha, Shyamaji Krishnavarma, and Bhagwanlal — were identified, despite the fact that the orthography of the two Indian names had only partially survived the trip to Europe: although intelligible, they are both misspelled There was a short text that explained the meaning of an image that was, on its own, difficult for the majority of the readers to understand: the renowned Italian professor of Sanskrit and Indian literature Angelo de Gubernatis-who was at that moment traveling through India in order to study the customs, languages, myths, and religious traditions of that "mysterious and interesting people"-had been made a Brahman. As one cannot convert to Hinduism and can only be a Brahman if one is born into the caste, Gubernatis had been the object of a religious ceremony of purification-perhaps we should call it a ceremony of upanayana ("initiation", the ceremony by which a guru initiates a boy into his caste by giving him the sacred thread), because its central gesture was to receive the sacred thread. In this way, he acquired the legitimacy to contact the sacred—visiting temples, talking to Hindu panditas, acquiring religious artifacts for his museum, observing religious events— the main

\footnotetext{
5) It is almost certain that at least one copy of the original photograph remains in Angelo de Gubernatis' archive kept at the manuscript section of the Biblioteca Nazionale Centrale di Florence, but the archive is still being catalogued and organized, and the photograph has not yet been found.
} 
objective of his voyage to India. According to Gubernatis, it was the Sanskrit-speaking pandit Bhagwanlal who offered to transform what had been the simple act of dressing up and being photographed as a Hindu Brahman into an actual religious initiation ceremony in which he was presented with the sacred thread of the Brahmans, in recognition of his profound knowledge of the Hindu religion. ${ }^{6}$

A few days after the photograph was taken, Gubernatis was honoured by, and elected to membership in, one of the most important learned institutes in British India - the Bombay branch of the Royal Asiatic Societybut this was not enough. Committed to a strategy of self-promotion in India and in Italy, Gubernatis took full advantage of modern developments in the reproduction and circulation of images and texts in order to increase the public resonance of his trip. He thereby not only made sure that the Italian public knew about his Sanskrit speech at the Asiatic Society $^{7}$ but also guaranteed that the same public could see his portrait dressed as an Hindu Brahman, photographed with three members of the Indian intellectual elites that lent legitimacy to his role as the pre-eminent Italian Indianist.

In addition to using the Italian press to promote his journey, Gubernatis wanted to do the same in India, as this meant he could reach the Indian elites he wanted to become involved with. The two main objectives of his journey were the acquisition of objects for the creation of an Indian Museum in Florence and the consolidation of a network of Indian contacts that could support the Italian Asiatic Society that he wanted to establish. ${ }^{8}$ His long journey in India and the museum and society he

6) Biblioteca Nazionale Centrale di Firenze, MS Angelo de Gubernatis [II, IV, 674], Relazioni del suo viaggio nell'India, autogr. (1885-6): 86; A. de Gubernatis, Peregrinazioni indiane, India centrale (Florence: Niccolai, 1886): 1:91.

7) On 14 October 1885 Angelo de Gubernatis was elected honorary member of the Bombay Branch of the Royal Asiatic Society. The ceremony began with the speeches of various members, including Gerson da Cunha, and finished with de Gubernatis's conference on "Indian Studies in Italy," in Sanskrit. It was thought to be the first time that someone had spoken in Sanskrit at the Society, where the usual language of public address was English. The various speeches were published in the journal's section "Abstract of the Society's Proceedings", The Journal of the Bombay Branch of the Royal Asiatic Society 43 (1885): xxvi-xxxiii.

8) The Società Asiatica Italiana was created upon de Gubernatis' return to Florence, in 1886. Inspired by analogous societies in Great Britain and India, its aim was to unite those who were interested in Asia as a subject and to promote in Italy the studies on Asia. It also aimed to promote contemporary relations between Italy and Asia. It encouraged the 
created upon his return in 1886 also helped affirm his scholarly authority and his status as a cosmopolitan intellectual able to move as an intermediary between the new Italian nation (which had recently been unified) and the rest of the world.

Gubernatis publicized this event in various kinds of texts, available to various publics. In his intimate description of the ceremony, Gubernatis revealed his religious ambivalence and the way in which, without abandoning Christianity, he accepted his new status as a Brahman and "honoured Brahma" as he did "Christ." "In a short article he wrote for the leading Florentine newspaper, La Nazione, however, Gubernatis felt the need to be more assertive in his Christianity for his readers. He had been born a Christian and would die a Christian and justified his participation in the ceremony by claiming that the possibility of being the protagonist of a ritual enacted by someone of Bhagwanlal's stature was an enormous honour for an Italian scholar who so admired India. ${ }^{10} \mathrm{He}$ also stressed that what others might view as a meaningless event was, for him, a solemn blessing that announced his pilgrimage through India's holy places: "one of these learned Brahmans, recognizing me as a Brahman like them, following sacred rites placed upon me the sacred thread that identifies me as a true Indian pandita. Thus, I lived amongst them, studied them, and observed in detail everything that interested me about this religious life."11

The image itself or the description of its making had an impact in various places. In Calcutta, the musician Pramod, the son of Sourindro Mohur Tagore, the founder of the Bengal Academy of Music, ${ }^{12}$ read Gubernatis' description of the ceremony in the Bombay Gazette with great interest and

participation of Asian members, mainly Indians. One of the aims of de Gubernatis' journey to India was to meet the members of the Indian elites- princes, pandits, and scholarsthat might become members of the Italian Asiatic Society.

9) Gubernatis, Relazioni del suo viaggio: $101 \mathrm{v}-102 \mathrm{v}$.

10) Gubernatis, Peregrinazioni Indiane: 1:90.

11) A. de Gubernatis, "Un italiano in India: Bombay, 14 ottobre," La Nazione, 6 November 1885: 2. For an analysis of the conversion rites practiced by the Jesuits in India and for the case of Nobili, a Christian who, like Gubernatis, immersed himself, for different reasons, in Hindu religious rites, see I.G. Županov, Disputed Mission. Jesuit Experiments and Brahmanical Knowledge in Seventeenth-century India (New Delhi: Oxford University Press, 1999).

12) Raja Sir Sourindro Mohun Tagore (1840-1914) was the founder of the Bengal Music School (1871) and the Bengal Academy of Music (1881) and doctor in music at the University of Philadelphia (1875). Belonging to a prosperous and liberal Bengali family, he was educated in a mixed culture, Indian and European. He became well known for his work on 
stated that he was "proud to see your devotion to our dear India."13 The echoes of the purification ceremony, which Gubernatis had described as a Brahman investiture, even reached Rio de Janeiro. The emperor of Brazil, Pedro II (1825-1891), wrote to Gubernatis in Italian to ask him to send him one of the photographs "in which he is pictured with Bhagwanlal and Gerson da Cunha"; the emperor also regretted having nothing to send him, because the study of Sanskrit in Brazil was little more than a curiosity for a few specialists. ${ }^{14}$

When, in 1886, Gubernatis finally opened the Indian Museum in Florence with the materials he had collected in India, all of the items that were used in the religious ceremony that preceded the taking of the photograph were displayed in a glass case, alongside other Muslim, Christian, and Hindu items. An entry in the museum's catalogue identified the "complete set of Brahman robes, including turban, sacred thread, and uttariya, ${ }^{15}$ worn by an Italian pandita on the day of his investiture in Bombay," while another described the "threads and sandalwood worn during the consecration of a new Brahman in Bombay on 10 October 1885." ${ }^{\prime 6}$ The catalogue entries do not mention Gubernatis's name, nor did they need to, because almost every object in the museum was connected with his journey.

As far as we know, the only negative reaction to the image, which was related to the context in which it was presented in L'Illustrazione Italiana, came from José Gerson da Cunha, one of the men in the photo. Da Cunha (1844 Goa-1900 Bombay), a Christian Goan physician and historian living in Bombay, was the only Indian to take part in the Fourth International Congress of Orientalists, in Florence in 1878, which is where he first met Gubernatis. ${ }^{17}$ In an Orient of uncertain boundaries that changed with

Hindu music and was the author of poems set to music, in Sanskrit and in English, dedicated to Queen Victoria and the Prince of Wales.

13) BNCF, MS, Correspondence Angelo de Gubernatis, Box 154, letter from Pramod Kumar Tagore (Calcutta, Pathuria Ghata Raj Bati, 18 November 1886).

14) BNCF, MS, Correspondence Angelo de Gubernatis, Box 154, letter from Pedro d'Alcântara (Rio de Janeiro, 5 October 1886).

15) A piece of cloth, usually made of cotton, which is commonly used as a scarf.

16) Catalogo del Museo Indiano (Florence: Le Monnier, 1887): 74-7.

17) José Gerson da Cunha (1844 Goa, 1900 Bombay). On his life and works see: G.M. Moraes, “Dr. José Gerson da Cunha: 1844-1900. Memorial Volume," Journal of the Asiatic Society of Bombay, new ser.1964-5 (1967): 39-45; J. Gerson da Cunha, Francisco Caetano da Cunha e sua familia (Nova Goa: Tip. da Casa Luso-Francesa, 1925); J.B. Amâncio Gracias, "Notícia necrológica e biográfica de Gerson da Cunha," O Instituto 48/1 (1901): 47, 49; He published many articles on the Portuguese presence in India, mainly in the Journal 
the political and personal whims of those organizing the conferences, the lectures on India and the Oriental Exhibition taking place simultaneously in one of the Medici palaces were the highlight of the Florentine conference. This was the beginning of an intense friendship between the two men, a friendship of intellectual rapport and mutual admiration that was expressed through seven years of correspondence between Florence and Bombay. When they finally met on Indian soil in 1885 , Gerson da Cunha was able to repay his friend's hospitality by acting as his intermediary and guide in Bombay, introducing him to his wide circle of friends and scholars, accompanying him on ethnographic and archaeological trips, and helping him to collect exhibits for the Indian Museum of Florence. The gathering in the photographic studio took place in this context, shortly after Gubernatis's arrival to Bombay.

However, emerging from this meeting in India that both men had so desired were some misunderstandings that were brought into the open only when Gubernatis, on his return to Italy, wrote a letter to Gerson da Cunha saying everything he had not said while in India. ${ }^{18}$ In his angry reply, Gerson da Cunha accused Gubernatis of various things, including the inappropriate captioning of the photograph: "did you ask me for permission to call me a gentile in the Illustrazione Italiana?" 19 It was clear that Gerson da Cunha did not like being described in the caption as one of the "Bombay Brahmans." Despite the fact that the text accompanying the image clearly stated that Gerson da Cunha was a "Christian Brahman from Goa," who had previously visited Italy to take part in a conference of Orientalists, and despite the reference to his title of "Doctor," which identified him as a surgeon, the photograph's caption, which was more obvious and closer to the picture, made no mention of him being a Christian. The word "gentile" was entirely absent from the newspaper article, but Gerson da Cunha knew that most people believed that being a Brahman meant being a Hindu and not a Christian, which in turn meant being a "gentile" or

of the Bombay Branch of the Royal Asiatic Society, but also in the Indian Antiquary. See also J. Gerson da Cunha, "Materials for the History of Oriental Studies Amongst the Portuguese," in Atti del IV Congresso Internazionale degli Orientalisti tenuto in Firenze nel Settembre 1878 (Florence: Le Monnier, 1881): 2:179-219.

18) We found only the letter of reply from Gerson da Cunha to Gubernatis. We do not know where the other side of this correspondence is - the letters from Gubernatis to Gerson da Cunha. We can thus deduce Gubernatis' accusations to Gerson da Cunha only by reading his replies.

19) BNCF, MS, Correspondence Angelo de Gubernatis, letter from José Gerson da Cunha, 44

(39 Hornby Road, Bombay, 13 July 1886). 
"heathen," a word that, in the context of his Goan Catholic upbringing, was considered offensive. What was it that had offended Gerson da Cunha? Was it seeing himself represented in a way he did not recognize, or was it the possibility that others-in this case "Europeans" and "Catholics"would see him as other than he was? Who were the observers with whom Gerson da Cunha was so concerned? Were they the Italians, whose country he chose as his Europe, or the Goans who, in both Goa and Bombay, would probably have been surprised to see a Catholic dressed as a Hindu Brahman, in an apparently serious photograph?

More surprising, however, is that one year before the two men fell out, a short time after the photograph was taken, Gerson da Cunha wrote to Gubernatis, who was still travelling through India, informing him of the arrival of "two photographs of a group of gentiles" that was his own "share of the photographic enterprise." ${ }^{20}$ In this letter to his friend, in a context that lent itself to both intimacy and irony, Gerson da Cunha was able to joke about the "group of gentiles," of which he was one, as if it were a deliberate performance by a group of men united by friendship and erudition. Once the reproduction of the photograph appeared in the illustrated Italian newspaper, however, Gerson da Cunha became aware that his identity might be perceived in another way, as one of three Indians, apparently Hindus, who served to contextualize Angelo de Gubernatis in the location from which the photograph was sent. In Lillustrazione Italiana, Gerson da Cunha became part of what might be perceived as a group of exotic wise men from a faraway land, legitimizing the knowledge of Italy's most illustrious Indian specialist. His Indianness was reinforced, while the elements of his European identity-his Goan culture, his mother language, his Catholic religion and education-became almost invisible. Gerson da Cunha's reaction to the possible interpretations of the publicly exhibited image reveals that the image was unable to resolve the conflicts that arose before its making. In fact, the photograph was the result of a series of negotiations concerning who would and who would not be photographed.

\section{Negotiating Identities: Who Should Be Photographed and Why?}

If the image, its caption, and the accompanying text in the Lillustrazione Italiana suggest to us hybridism and ethnic, religious, or national syncretism,

20) BNCF, MS, Correspondence Angelo de Gubernatis, Letter from José Gerson da Cunha, 39 (Hornby Road, Bombay, 5 November 1885). 
then the texts that describe the preparations for the photograph reveal the more or less hidden conflicts among those being photographed and those not being photographed. Gubernatis and Bhagwanlal were the only two in the photograph who were present throughout the process, including the planning and the taking of the picture. Gubernatis had already heard of this "learned and holy Brahman"-who was a specialist in Sanskrit, epigraphy, and numismatics-before his arrival in India. He also knew that he had used his skills and knowledge to assist British, German, and Dutch scholars and that the University of Leiden listed him as one of its correspondent professors. ${ }^{21}$ In Bombay, Bhagwanlal became one of Gubernatis's closest aides and his main contact with sacred India. It was he who, at the beginning of October 1885, a short time after Gubernatis's arrival in India, accompanied the Italian to order "Brahman robes" much like the ones he wore every day. ${ }^{22}$

That the subjects would be photographed in "Brahman robes" was soon assumed, but who would be in the photograph next to Gubernatis? While the robes were being made, a few potential candidates were considered: Canta-Ram Narayana, a Brahman lawyer whom Gubernatis knew from Gerson da Cunha's literary salon, and his pregnant daughter, who recited the Shakuntala in Gubernatis's honour, "would also be photographed with me, dressed in Brahman robes." ${ }^{23}$ When Gerson da Cunha's wife, Ana Rita, heard that another woman might be joining them, she too expressed an interest in being part of the portrait. ${ }^{24}$ According to Gubernatis, however, the problems began just as "everything was almost ready for our appearance in front of the camera."

When her initial enthusiasm had cooled, Gerson da Cunha's wife regretted her resolution and no longer wished herself or her husband to be photographed. Gubernatis wrote in his personal diary that it was probable that her Catholic priest had forbidden her to be photographed with "Indians." 25 In his published account of the journey, however, this change of mind was no longer blamed on a single priest but on Catholicism in general and on the fear she might have had of the reception the photograph might receive in Goa. ${ }^{26}$ Ana Rita argued that the image of three Catholics-herself, her

\footnotetext{
21) A. de Gubernatis, Peregrinazioni Indiane. India Centrale (Florence: L. Niccolai, 1886): 1:60.

22) Gubernatis, Relazioni del suo viaggio: 77.

23) Gubernatis, Relazioni del suo viaggio: $74 \mathrm{v}$.

24) Gubernatis, Relazioni del suo viaggio: 90v-91.

25) Gubernatis, Relazioni del suo viaggio: 90v-91.

26) Gubernatis, Peregrinazioni Indiane: 1:87.
} 
husband, and Gubernatis-dressed as Brahmans would be a source of ridicule in her Goan family. The problem was not so much with Catholics being photographed dressed as Brahmans for a "bit of fun" as it was with being photographed with actual Brahmans in an image that apparently had nothing to do with a "masquerade."

According to Gubernatis, Gerson da Cunha, when confronted with his wife's position, also had a change of heart and decided not to be photographed, invoking religious differences as his main reason. In the privacy of his diaries, Gubernatis could blame the enormous influence Ana Rita had on her husband and reveal his difficulty in understanding the religious incompatibility between Hindu Brahmans and Catholics that were also Brahmans: both Gerson da Cunha and his wife were of "ancient Brahman blood," and Gubernatis thought that they could assume their caste without offending their Catholic religion. Gerson da Cunha suggested taking another photograph, including only Catholics, but Gubernatis refused to take part in a representation determined by religion. He had not travelled from Italy to India to be photographed with Catholics.

In the account of this episode published in Peregrinazioni Indiane, Gubernatis expressed his profound disagreement with "Mrs da Cunha": there was nothing light-hearted about the photograph, his Brahman robes were sacred, and it was with a sense of pride that he would be pictured alongside "real Indians" of that rank. In the privacy of his unpublished travel journal, however, he had the freedom to write that Ana Rita's "problem" was that she wanted to "pass for a European." ${ }^{27}$ By revealing his intolerance of an individual identity he believed to be too hybrid, he could be counted among those travellers who found it more difficult to deal with sameness than with difference. Goass case could be particularly puzzling to British travellers' expectations of India. Isabel Burton, for example, the wife of the famous traveller and writer Richard Burton, was also condescending towards the European dress, gestures, and traditions she found amongst the Goan Catholic elites in Pangim (Panaji) ${ }^{28}$ Both Isabel Burton and Gubernatis were prepared to witness and to accept India's differences, but they both had difficulties dealing with the cultural similarities embedded in ethnic difference. As they searched for "true" Indianness, finding

27) Gubernatis, Relazioni del suo viaggio: 90v-91.

28) I. Burton, AEI: Arabia, Egypt, India: A Narrative of Travel (London and Belfast: William Mullan and Son, 1879): 302-5. 
"others" who were "like them" could unsettle their most deeply rooted expectations.

In his personal diary (but not in the published version), Gubernatis wrote that Gerson da Cunha wore an accessory that further complicated his religious identity: as both men were changing out of their European clothes in the photographic studio, the Italian noticed that Gerson da Cunha was wearing a necklace. ${ }^{29}$ Gubernatis was surprised to see his Catholic friend wearing around his neck something that he identified ethnographically as the phallic symbol of the ancient Deccan Saivaite, but when he asked Gerson da Cunha why he was wearing the trinket, the doctorwho had been educated in Bombay, Edinburgh, and London, in the colonial and metropolitan circuit of Western medical knowledge available to the inhabitants of British India_-replied, according to Gubernatis, that it was simply an African stone that protected him from sore throats. On seeing his Italian friend's surprise, Gerson da Cunha seems to have preferred to raise doubts about his credibility as a doctor trained in Western science than about his Catholicism. Both Gubernatis and Bhagwanlal pretended to be satisfied with his explanation, although the former confided in his diary that this was proof that the Christians of the region preserved many pagan traditions.

This story, like many others confided to the intimacy of his private Indian travel diary, demonstrated Gubernatis's contradictory feelings about what he identified as Gerson da Cunha's hybrid identity. The friendship that had been born in Florence was blemished a few years later by their close companionship while in India. Meeting daily in Bombay, in Gerson da Cunha's environment, Gubernatis often revealed his difficulties in understanding the former's multiple identities, his diverse intellectual and cultural references, and the kind of Catholicism that allowed him to wear not a cross but a phallic symbol on his chest. Within this religious hybridism that Gubernatis found so difficult to understand there was also much he had in common with Gerson da Cunha. The Italian was raised and educated as a Catholic but was criticized by some of his compatriots for betraying Christianity and harbouring an excessive enthusiasm for Hindu culture. ${ }^{30}$ His dislike of Gerson da Cunha's wife led Gubernatis to blame her for other things: by withdrawing from the photograph she had also

\footnotetext{
29) Gubernatis, Relazioni del suo viaggio: $102 \mathrm{v}$.

30) C.A. de Cara, Errori mitologici del professore Angelo de Gubernatis (Prato: Tipografia Giachetti, 1883).
} 
caused the other woman who was to be photographed-the daughter of Gerson da Cunha's friend, the Hindu lawyer-to be excluded. ${ }^{31}$ Because the photograph was going to place Catholics and Hindus side by side, Ana Rita asserted that they should all be "learned." Despite being the daughter of a Hindu lawyer and, according to her proud father, one of only five hundred women in all of India capable of reciting the Shakuntala, her gender, reinforced by her evident pregnancy, excluded her from the "learned" category. This led Gubernatis to write, in his private diary, that the only truly learned man in the photograph was Bhagwanlal. ${ }^{32}$ While the image says nothing about questions of gender - the women are not present, and their absence is not even noted-the texts reveal that they too were involved in the negotiations over who should be in the group. In this context, gender was not necessarily a relevant factor when combined with religion (Catholic or Hindu) or caste, but once "erudition" became the criterion, women were excluded from the photograph, even if this exclusion was, according to Gubernatis, the result of a decision taken by a woman. We thus see how the criteria for inclusion in or exclusion from the photograph were altered: matters of gender, religion, and caste were involved, but it was finally a vague notion of common knowledge that dominated: "We will see how this farce ends," Gubernatis lamented, expressing his inability to alter the unexpected consequences of his decision to be photographed in Brahman robes.

The fourth person in the image-in addition to Gubernatis, Gerson da Cunha, and Bhagwanlal-is Shyamaji Krishnavarma (1857 Mandvi, Kutch, 1930 Geneva) who happened to be in Gerson da Cunha's home the day before the photograph was taken. In addition to being a Hindu and a Brahman, Krishnavarma was an erudite person. ${ }^{33}$ Gubernatis had met him in 1881, at the International Congress of Orientalists in Berlin, which Krishnavarma attended as an expert in Vedic philosophy and religion. His relationship with Gerson da Cunha was older. In 1879, as a young, promising, and practically unknown scholar, Krishnavarma was Gerson da Cunha's private secretary and Sanskrit teacher. ${ }^{34}$ When Krishnavarma had

31) Gubernatis, Relazioni del suo viaggio: 99.

32) Ibid.

33) R. Visram, Asians in Britain: 400 Years of History (London: Pluto, 2002): 150-2; I. Yajnik, Shyamaji Krishnavarma: Life and Times of an Indian Revolutionary (Bombay: Lakshmi, 1950).

34) Krishnavarma taught Gerson da Cunha during the first half of 1878, and the high regard in which he held his tutor was evident in the letter of recommendation he wrote for 
the opportunity to teach at Oxford as an assistant to the renowned Sanskrit expert Sir Monier-Williams, Gerson da Cunha lent him money for the voyage to Britain. Gerson da Cunha classified his own gesture of generosity as a "small material contribution towards the progress of this land," a way of contributing to the knowledge of India by helping a bright young scholar. ${ }^{35}$ Krishnavarma took advantage of his time in Britain to study law at Balliol College, where he became the first Indian to be awarded an MA from Oxford. By 1884, he was back in India practising as a lawyer in the Bombay court. ${ }^{36}$ Married to the daughter of a rich Bombay merchant, he had also been appointed advisor to the minister for Ratlam, in Madhya Pradesh, before going back to Britain in 1897 and remaining in Europe until his death in 1930, in Geneva. By the time of the photograph, in 1885, Krishnavarma, who had only recently returned from Britain, no longer needed to make a living by cataloguing Gerson da Cunha's Indian coin collection or teaching him Sanskrit. His passage to the imperial metropolis meant a change of position when he settled again in India. The knowledge of Sanskrit was common to the four men, although Indraji was more interested in religious practice, Krisnavarma and Gubernatis were teaching Hindu literature and culture, and Gerson da Cunha was more interested in history and archaeology.

On the day of the photograph, Gubernatis transformed himself into his own ethnographic subject, carefully observing all the rituals in which he took part, in order to describe them later in his travel diaries. From his arrival at the photo studio until the moment Bhagwanlal put the sacred thread on his chest and made a mark on his forehead, which he identified as the sign of lakshana, joyfully exclaiming "here is a true Brahman!," Gubernatis became both a protagonist and an observer of the ritual. ${ }^{37}$ But even though, in his texts, he described in minute detail all of Bhagwanlal's gestures and orations, the photograph that concluded the ceremony bore no trace of the action that had preceded it. It became a classic group portrait, in which everyone was posing. Studios normally have a room in

\footnotetext{
him (Yajnik, Shyamaji Krishnavarma: 27). We do not know whether this was the first time Gerson da Cunha had taken Sanskrit lessons and whether his knowledge of the language went further than the ability to read documents for his historical studies.

35) Yajnik, Shyamaji Krishnavarma: 27, 34-5; BNCF, Manuscripts, Correspondence Angelo de Gubernatis, Letter from José Gerson da Cunha, 16 (Hornby Road, Bombay, 17 March 1879); Gubernatis, Peregrinazioni Indiane: 1:87-8.

36) Yajnik, Shyamaji Krishnavarma: 7.

37) Gubernatis, Peregrinazioni Indiane: 1:89.
} 
which those being photographed can prepare themselves. In this case, the idea of transformation inherent in these spaces took shape through the Hindu religious ritual under the Vedic rite of brahmatva, which "transformed" Gubernatis into a Brahman, thus preparing him for his religious exploration of India. Both events- the ceremony and the photograph that followed-marked the transition between Bombay, a sort of initiatory antechamber, and another India where he could assume his role as a "pilgrim of science."

Both literally and metaphorically, Bhagwanlal removed Angelo de Gubernatis's European clothes and slowly and delicately dressed him in his new Indian robes and with the sacred thread. ${ }^{38}$ By tradition, it was forbidden for a man to study the Vedas and the sacred rituals - and only men were permitted to do so-without first having received the sacred thread that was worn under the clothes, next to the skin. By being presented with the sacred thread, Gubernatis was recognized as an expert in the Hindu faith and had more legitimacy in entering holy spaces, appearing before religious leaders, and acquiring items for the museum he intended to establish in Florence. When, during his journey through India, the Brahmans of a temple told him that he could not purchase a pumpkin in the shape of an idol, Gubernatis opened his shirt and showed them his sacred thread. They immediately relented and, in addition to selling him the pumpkin, offered him some sandalwood, a small bird, and a paper fan. ${ }^{39}$

As Gubernatis himself admitted during his travels, a Christian dressed as a Brahman, or disguised as one, was not unusual. At the Jesuit church in Madurai he noticed portraits of two Italian missionaries dressed as Brahmans (sannyasis), one of whom was the famous missionary Roberto Nobili. ${ }^{40}$ Gubernatis deeply regretted not having a camera with which "to take with him these two portraits that would be a worthy decoration for the Indian Museum of Florence." ${ }^{11}$ By photographing these paintings, he

\footnotetext{
38) Ibid.: 1:88.

39) A. de Gubernatis, Peregrinazioni Indiane, vol. 2, India meridionale e Seilan (Florence: L. Niccolai, 1887): 74-5.

40) According to Gubernatis, these were copies of originals kept in Rome, where they had been painted by local artists: Gubernatis, Peregrinazioni Indiane: 1:263-4. On Roberto Nobili and the Jesuits knowledge of India in the seventeenth century, see Županov, Disputed Mission.

41) The only similar image in the Indian Museum was a photograph of Tyrrell Leith dressed as a Muslim (Catalogo del Museo Indiano: 56, 68-9, 71, 88).
} 
would have taken back to Florence a proof of religious syncretism, while legitimizing his own gesture in dressing as a Brahman before the Italian public.

Unlike almost all other cases in which Indians and Europeans were photographed together in a colonial context, the clothing worn in this photograph reflects no ethnic differences. Because the only European in the photograph is dressed in the same way as the Indians surrounding him, only physiognomy can differentiate them. This raises a difficult problem: We have only a sketch of the photograph, not the photograph itself. Might the sketch artist in Milan, Mr Cavallotti, have emphasized the ethnic differences between those in the photograph? Gubernatis is, in fact, shown with light-coloured eyes, a fair beard, and white skin. Other photographs of Gubernatis show him to have had much darker skin and dark eyes. Did the artist, consciously or not, make Gubernatis appear whiter than he was and, perhaps, make the others darker, in order to highlight differences that were not obvious? Did Mr Cavallotti "de-nativize" an Italian who could not be distinguished from the Indians, in a photograph in which the colour of the turban as a mark of difference was more striking than the colour of the skin?

\section{Classifying Photography}

In recent years the number of studies on colonial photography has multiplied. These often emphasize both the diversity and the heterogeneity of the relationships between photographer and subjects. Most studies treating photography in a colonial context, however, still tend to privilege its role in the identification, classification, control, and affirmation of the colonial powers and "to see how photography has functioned to lend powerful support to the ideologies of cultural and racial dominance in the modern age." ${ }^{32}$ They are likely to concentrate on photographs taken in the colonies by photographers who are in a position of authority, either because they belong to that group that might be described as the colonizers or because they used forms of visual classification that were indistinguishable

42) E.M. Hight and G.D. Sampson, "Introduction: Photography, 'Race', and Post-colonial Theory," in Colonialist Photography: Imag(in)ing Race and Place, ed. E.M. Hight and G.D. Sampson (London: Routledge, 2002): 16; M.A. Pelizzari, "Introduction," in Traces of India: Photography, Architecture, and the Politics of Representation, 1850-1900, ed. M.A. Pelizzari (New Haven: Yale University Press, 2003): 13-8. 
from other tools of colonial knowledge. ${ }^{43}$ Photography, particularly when used in physical anthropology, including its popularized versions, was an important instrument in the diffusion of ideas about race in a West that derived knowledge of the East primarily from texts and images. These often reinforced racial preconceptions, strengthening the hierarchies that organize people and legitimizing the needs and ambitions of the colonial powers. The eight-volume photographic compendium, The People of India (1868-75), that sought to classify the different people of India in about five hundred captioned photographs, is just one example of this tendency. ${ }^{44}$

The exploration of the links between colonial knowledge and photographic production, which were certainly present, coexists with the desire evident in many recent studies to broaden the approaches to photography. While photography served a colonial culture as understood by Nicholas Thomas, it was also widely used by Indians, becoming one of the most popular modern technologies in India during the second half of the nineteenth century. ${ }^{45}$ Photography in the colonial context-which was not necessarily "colonial photography" - had many uses and meanings, and it would be too reductionist to define it simply as an instrument in the exercise of authority, in differentiating the active actions of the colonizers who

43) J. Tagg, The Burden of Representation: Essays on Photographies and Histories (London: Macmillan, 1988).

44) J. Falconer, "A Pure Labor of Love': A Publishing History of The People of India," in Colonialist Photography: Imag(in)ing Race and Place, ed. E.M. Hight and G.D. Sampson (London: Routledge, 2002): 51-83.

45) N. Thomas, Colonialism's Culture: Anthropology, Travel and Government (Princeton: Princeton University Press, 1994). For more on photography in India, see C. Pinney, The Coming of Photography in India (London: The British Library, 2008); M. Karlekar, Re-visioning the Past: Early Photography in Bengal 1875-1915 (New Delhi: Oxford University Press, 2005); Pelizzari, ed., Traces of India; ed. V. Dehejia, India through the Lens: Photography 1840-1911, exhibition catalogue (Washington DC: Freer Gallery of Art and Arthur M. Sackler Gallery, Smithsonian Institution, 2000); C. Pinney, Camera Indica: The Social Life of Indian Photographs (London: Reaktion, 1997); J. Falconer, "Photography in Nineteenth-century India," in The Raj: India and the British, 1600-1947, ed. C.A. Bayly (London: National Portrait Gallery, 1990); E. Edwards, ed., Anthropology and Photography, 1860-1920 (New Haven: Yale University Press, 1992); J. Falconer, ed., India: Pioneering Photographers 1850-1900, exhibition catalogue, Brunei Gallery SOAS (London: The British Library and The Howard and Jane Ricketts Collection, 2001); J.M. Gutman, Through Indian Eyes: 19th and 20th Century Photography from India (New York: Oxford University Press, International Center of Photography, 1982); R. Desmond, Victorian India in Focus: A Selection of Early Photographs from the Collection in the India Office Library and Records (London: HMSO, 1982). 
took the photographs from the passive actions of the colonized being photographed. In a debate that has developed in parallel with that surrounding the use of the term "orientalism" since Edward Said published his book in 1978 , the critical theory that has been dedicated to colonial photography today tends to question the presuppositions that limit photography to a relationship between knowledge and power, emphasizing the complexity and multiplicity of its uses in the colonial context. ${ }^{46}$

It is not possible to consider the photograph in question a colonial photograph in these terms. One the one hand, we must recognize that its production is inseparable from the colonial context in which the participants evolved, although the image seems to suggest different hierarchies and identities that cannot be seen solely through a colonial prism. On the other hand, it was those being photographed — and not the photographerwho made the decisions that led to the final image. As an observer, the Parsi photographer owned the camera and pressed the shutter release, but his involvement was as a passive witness. In the case of this image, the "difficult encounter" that sometimes is identified between the photographer and those photographed took place only between those photographed, but it was not necessarily a consequence of existing colonial hierarchies. Nevertheless, as we have seen, while those being photographed could be involved in the construction of the image, they were, despite all their efforts, unable to control its interpretation.

Can we then, from another perspective, compare this photograph with the orientalized images in which European subjects dress in Eastern clothes? In fact, the idea of disguise and staging had been a part of photography since its invention. Within this kind of photography, visual orientalism was one of the most popular ways to make use of difference to construct an image of oneself, as was also true of the pictorial tradition of the portrait. ${ }^{47}$ During the second half of the nineteenth century and the first part of the twentieth, there was a proliferation of photographs of Europeans dressed in oriental costume, either at masquerades or in the studios of photographers who supplied the necessary props, clothing, and backdrops

46) E.W. Said, Orientalism (London: Routledge and Kegan Paul, 1978); Hight and Sampson, "Introduction": 1-19; J.R. Ryan, Picturing Empire: Photography and the Visualization of the British Empire (London: Reaktion, 1997); J.M. Schwartz and J.R. Ryan, ed., Picturing Place and the Geographical Imagination (London: I.B. Tauris, 2003).

${ }^{47)}$ K. Jacobson, Odalisques and Arabesques: Orientalist Photography 1839-1925 (London: Quaritch, 2007); N. Tromans, ed., The Lure of the Orient: British Orientalist Painting (London: Tate Publishing, 2008). 
for the transformation..$^{48}$ More important than identifying the geographic location in which the costume was worn or the ethnographic accuracy of the result was the evocation of an Orient that everyone could recognize as such, even if no one knew where it actually was.

In our image, however, Gubernatis was not simply dressed as an Indian Brahman, he was somehow assuming the identity of an Indian Brahman, and everything that he wore was "genuine," legitimized and sacralized by Bhagwanlal Indraji. Just as Richard Burton "went native" in order to travel incognito, Gubernatis wished to mitigate the differences with those he wanted to meet, because this blurring of identities would allow him to get closer to the object of his interest, religious India, which, for him, meant mainly the Hindu religion. ${ }^{49} \mathrm{He}$ also participated in ceremonies and collected objects from other religions, as he did in the Parsi community of Bombay, for example, but the India he wanted to exhibit in Florence was Hindu India. It also seems that the photographic studio had not been made to look Indian. Indeed, our image is distinguished by its restraint and by the absence of the excess that is normally associated with a staged Orient. Even the ethnographic and religious rituals that preceded the photograph are absent from the image. More than the costumes and complexions of the subjects of the photograph, it was the text accompanying it that linked the image to India. This inseparability again argues for the need to approach text and image from the same historiographical point of view. We could also question an attempt to classify this image solely because it was produced in a non-Western space. We should accept that, as happened with photography produced in Europe or the United States during the second half of the nineteenth century, photography in non-Western places that were in some cases also colonized assumed a diversity too difficult to restrict to specific categories.

One of the main disputes in deciding who was to be photographedwhich led to Gerson da Cunha and his wife Ana Rita agreeing and then refusing to be part of the planned photograph-concerned the difficulties in defining the border between the genuine and the false, between robes and costume, between reality and masquerade. While Bhagwanlal Indraji and Krishnavarma were dressed in their everyday clothes consistent with

48) M. Roberts, Intimate Outsiders: The Harem in Ottoman and Orientalist Art and Travel Literature (Durham: Duke University Press, 2007).

49) D. Kennedy, The Highly Civilized Man: Richard Burton and the Victorian World (Cambridge MA: Harvard University Press, 2005): 46, 51-5. 
the tradition of Hindu Brahman pandits, Gerson da Cunha was not photographed in his usual garments. He was the only one in the photograph who was wearing a costume to disguise himself and, according to Gubernatis, he did so with some repugnance and only to please him (Gubernatis). ${ }^{50}$ Separated from his Catholicism, the evocation of his Brahman caste seemed to make him uncomfortable, because, in the social and cultural context of Portuguese India, each category needed the other in order to constitute a sign of social distinction. ${ }^{51}$

\section{The Men Portrayed: Agency, Knowledge, and Mobilities}

This image might undermine some of the premises used in the study of colonial photography, and the paths followed by those photographed, as well as their relationships with one another, were not easily reconciled with the usual positions assigned to the colonized. They all lived in a colonial environment, but they were all characterized by the geographical mobility and fluidity of the positions they occupied as producers of knowledge about India and by the impossibility of placing them in such categories as "colonizers" and "colonized." The photograph that brought them together, published in a newspaper in an Italy that was beginning to aspire to its own colonial project, could never have been found in a colonial historiography written from a nationalist perspective. The same might be said of the four participants.

The men in the photograph, with Indraji's exception, lived in a world of frontiers in the process of being defined, frontiers that they reinforced, criticized, or questioned. Standing in-between different worlds they reinforced the ever more central idea that there were many ways of being and of living in colonial contexts, and that the "colonized" could have different ways of relating to colonial agents, institutions, and discourses. There are more useful ideas - than the categories of collaboration or subalternity, of complicity with the colonial regime or resistance to it, of Europeanization or of Indianization— to help us understand them better as participants in a colonial world.

\footnotetext{
50) Gubernatis, Relazioni del suo viaggio: 102 rv.

51) Ângela Barreto Xavier has made the same point in her many studies of Goa, e.g., her "David contra Golias na Goa seiscentista e setecentista. Escrita identitária e colonização interna," Ler História 49 (2005): 107-43, 117-9.
} 
They were all involved in producing knowledge about India, they all had agency, initiative, voice, and authority in the construction of an India that was increasingly being identified, described, collected, exhibited, photographed, and historicized..$^{52}$ But if colonial knowledge means knowledge that is produced or instrumentalized by the colonizing power, this does not help us to understand the heterogeneity of the discourses of the colonized. The meaning of such participation was not monolithic: sometimes they contributed to discourses that were indistinguishable from European colonial initiatives, but at other times their contributions enhanced an Indian culture that could be used as a way of legitimizing a path to nationalism, where the British presence would no longer have a place—or which could be used to value a Goan culture seen as different from that of Portugal or from that of the rest of India.

There were many Indians taking part in the various efforts to know India, but some ways of participating in this dialogue involved more agency than did others. In many cases, Indians worked as collaborators, intermediaries, or interpreters for British or Europeans: excavating archaeological sites; photographing, drawing, or gathering surveys of peoples or objects; copying inscriptions; collecting objects or manuscripts; translating texts (which often meant preparing the materials that would then be used by others, mostly Europeans). These kinds of cultural relationships had an obvious hierarchy: Indians were the intermediaries between the objects of study and the producers of knowledge, but they were not the ones who signed the final product.

In many other cases, however, and increasingly during the second half of the nineteenth century, Indians were producing knowledge in their own names and had their work recognized by their contemporaries. Despite being fewer than their European counterparts, a significant number of Indians actively participated in this exchange of knowledge-writing in scholarly journals, presenting papers at international congresses, belonging to learned institutions such as the Asiatic Societies, or being members of

\footnotetext{
52) The recent work on the production of knowledge in colonial contexts, specifically in India, is vast, e.g., B.S. Cohn, Colonialism and Its Forms of Knowledge: The British in India (Princeton: Princeton University Press, 1996). R. Inden, Imagining India (London: Hurst, 2000); P.B. Wagoner, "Precolonial Intellectuals and the Production of Colonial Knowledge," Comparative Studies in Society and History 45/4 (2003): 783-814; Tapati GuhaThakurta, Monuments, Objects, Histories. Institutions of Art in Colonial and Postcolonial India (New York: Columbia University Press, 2004).
} 
the commissions that organized the representations of India at exhibitions, in India or in Europe.

This participation was not free from conflict and hierarchy. Even the work of those Indians who had an individualized voice in the scholarly construction of India was often subordinated in various ways, in the process of revealing a specific knowledge or by subsequent historical constructs, which simply omitted, ignored, or subordinated their agency. Many Indians_-such as Gerson da Cunha, Bhagwanlal, and Shyamaji Krishnavarma - therefore had an active role in this process, not as collaborators but as protagonists, although history tended later to erase them from the contexts of cultural production, in what amounted to another form of intellectual colonization.

As we have seen in Shyamaji Krishnavarma's case, the same person could embody both kinds of agency. From what we know of his life until the year in which he was photographed, he was a paradigmatic example of a collaborator, a perfect symbiosis of local knowledge and knowledge produced in the metropolis. He went to Oxford to teach Sanskrit as an assistant to a renowned British orientalist. He studied law in Oxford and in London, after which he returned to India, where he occupied several prestigious positions within the judicial system that had been created by the British colonizers. In the mid-1880s, however, he became familiar with the Indian nationalist movements that were becoming increasingly prominent. ${ }^{53}$

The second part of his biography places him amongst those resisting colonialism or even makes him an active agent of its end. He returned to London some years after he posed for the photograph, although this time for a different purpose. He founded the India House in 1904, a residence for Indian students in London that was to become one of the centres of colonial resistance and the struggle for Indian independence. That same year he established the journal Indian Sociologist: An Organ of Freedom, and

53) In December 1885, two months after the photograph was taken, the first Indian National Congress meeting was held in Bombay, the first of many meetings of Indians, motivated by more or less assumed ideas of independence and nationalism: Report of the First Indian National Congress Held at Bombay on the 28th, 29th and 30th December 1885 (Lucknow: G.P. Varma \& Brothers, 1885); The Indian National Congress 1885-1985: An Exhibition in the British Library to Mark the Centenary of the First Meeting of the Indian National Congress at Bombay in December 1885 [30 November 1985-February 1986] (London: British Library, 1985). This catalogue published a photograph of all those who took part in this congress. That Krishavarma was dewan (chief minister) of Ratlam and that he was not in Bombay at the time of the congress perhaps explains his absence. 
of Political, Social and Religious Reform, in which he published his critiques of the British colonial government's despotism. As one of the most active voices in favour of a peaceful transition to Indian independence, he became a freedom fighter who was later regarded as a precursor of Gandhi (who lived in the India House with others involved in the Indian independence movement). The categories of "collaborator" and "resister" thus seem too limiting for classifying Shyamaji Krishnavarma.

Bhagwanlal (d. 1888) was born in Junagadh in 1839, and it was he who best embodied the sacred India, the Sanskrit India, the India of Hindu Brahman culture. He was the most "Indian" of all those photographed and perhaps because of this, it was he whom Gubernatis most admired. He had never set foot outside India, even though, immediately after the photograph was taken, he told Gubernatis of his intense desire to visit Europe and take part in the next congress of orientalists in Vienna, provided the rules of his religion were not transgressed..$^{54}$ Bhagwanlal was considered an authority on classical Sanskrit and had already collaborated in the translation of the Laws of Manu and several other texts, always as an assistant to European orientalists.

When the traveller, translator, and writer Richard Burton and Foster Fitzgerald Arbuthnot, a member of the Bombay civil service and student of Indian and Persian literature, began to show an interest in the Kama Sutra, a third-century religious Sanskrit text, they hired Bhagwanlal to collate and compare the many versions of the manuscript and establish the final version that was to be translated into Gujarati and then into English. ${ }^{55}$ To help him in the process of establishing the text of the Kama Sutra, Indraji relied on Shivaram Parshuram Bhide, a student at the University of Bombay who knew Sanskrit and English. Indraji delivered the Kama Sutra to Arbuthnot, and he, in turn, passed it on to Richard Burton, whom history records as the translator of the celebrated text that was revealed to the West in $1883 .{ }^{56}$ In a clear example of the subordination of certain scholars

54) I believe he never travelled to Europe, despite Gubernatis's guarantee that his religious beliefs would be respected (Gubernatis, Peregrinazioni Indiane: 1:91).

55) Kennedy, The Highly Civilized Man: 215-6. According to James McConnonachie, it was Georg Bühler, a German student of India living in Bombay, who recommended Bhagwanlal, who had also collaborated with James Fergusson and James Burgess. See J. McConnachie, The Book of Love: In Search of the Kamasutra (London: Atlantic, 2007): xiii, 111-8, 122-7.

56) The Kama Sutra of Vatsyayana, Translated from the Sanskrit with Preface, Introduction and Concluding Remarks (Cosmopoli: Kama Shastra Society of London and Benares, 1883); The 
and knowledges to others, Burton received the glory and the recognition, despite the fact that his participation was effectively limited to proofreading the English text, adding some footnotes, and, possibly, writing the preface, or part of it.

As we see in this case, the chain of intellectual collaboration was not always limited to the partnership of European erudites and Indian assistants, but also included other forms of collaboration, such as that between Indians. Nevertheless, these relations were almost always shaped by a set of hierarchies of power, either assumed or implicit. ${ }^{57}$ As happened with so many intermediaries essential to the process of collecting, identifying, collating, transcribing, photographing, and creating knowledge of India, Indraji's name did not survive the journey between the knowledge produced by locals and the knowledge of the locale (India in this case), which tended to erase the role played by Indians in the study of India.

Gubernatis transcribed the dialogue he had with Bhagwanlal about the differences between European and Indian scholars, immediately after the photograph was taken. According to Bhagwanlal, Europeans knew how to work with the materials but lacked real knowledge of the subjects described, while the Indians knew a great deal but were unable to organize this knowledge into the form of a book. ${ }^{58} \mathrm{He}$ also confessed to Gubernatis that he lacked the ability to transform all of the material he had collected and all of the knowledge that he had accumulated and that he needed to work with a "European scholar capable of giving light and life" to the material that lay "like a dark and dead thing" in his hands. It seems, from his quoted words, that Bhagwanlal Indraji had interiorized a common colonial perspective on the ways of producing knowledge and the useful, but subordinate, role natives could have in the process. These different epistemological approaches - which were often stated by European orientalists but could also be assumed, as in this case, by Indian scholars- had an implicit hierarchy. While the locals had the benefit of belonging to the place they studied, it was Western scholars who usually had the tools to analyze it.

What about Angelo de Gubernatis? What, precisely, was his position in the geographical, political, social, and cultural spaces in which he evolved

Kama Sutra of Vatsyayana, trans. R. Burton and F.F. Arbuthnot, ed. W.G. Archer (London: Guild, 1990).

57) M.S. Lovell, A Rage to Live: A Biography of Richard and Isabel Burton (London: Abacus, 1998): 610-21; M.S. Dodson, Orientalism, Empire and National Culture: India, 1770-1880 (Basingstoke: Palgrave Macmillan, 2007): 10.

58) Gubernatis, Peregrinazioni Indiane: 1:91. 
and in the spheres of knowledge production on India? He travelled to India to be "Indianized," that is, to stop being an "imperfect, almost false, scholar of India" and to create an Indian Museum in Florence. ${ }^{59}$ The Italian had a passion for India but particularly for the India he imagined before leaving Europe - the India he had studied and taught about for so many years. He looked for and accommodated difference, but when India resembled Europe, he had more difficulty in accepting it. Gubernatis was the only European in the photograph, a European orientalist but from a Europe that had no connection to colonial India, which was dominated by Britain and where Portugal and France survived as minor colonizers, overshadowed by their neighbour.

His devotion to ancestral and learned India did not prevent him from being accompanied on his journey by two commercial agents, whose mission was to establish an Italian emporium in Bombay. ${ }^{60}$ Nor did it prevent him from imagining an India colonized by Italy, in which Diu-an island off the west coast of India, which he considered poorly exploited by the Portuguese-would be the first acquisition. His career and his written and personal relationship with India prevent us from employing monolithic definitions to identify him. Before travelling to India, Gubernatis had spent more than twenty years writing about it, creating institutes and journals dedicated to an "Orient" in which India was always the leading figure, and his early discourse was less focused on the present than it became later. His journey, however, represented a moment of transition in his discourse on the colonial position of an Italy that, in his words, "also wanted to leave home." In fact, in 1885, the year of his trip to India, Italy's colonial enterprise got under way on Africa's eastern coast, which meant, as Gubernatis noted, that India now lay much closer. His attitude towards British colonialism and the uses of an academic orientalism in exploring a colonial vocation were also ambivalent: from being openly critical of the abuse of

59) A. de Gubernatis, "Il viaggio nell'India ed il Museo Indiano," in A. de Gubernatis, Fibra: Pagine di ricordi (Rome: Forzani, 1900): 440.

${ }^{60)}$ De Gubernatis' journey to India was seen by the Italian government as an opportunity to send two men, Alessandro Albiani and Giovanni de Nobile, to explore the possibilities of studying and developing commercial relationships between the two countries. The different natures of their interests and personalities, as well as their different ways of seeing and living India, however, soon became obvious. De Gubernatis' diaries are full of complaints about the effectiveness of this mission, mainly with regard to the behaviour of De Nobile, who was finally sent back to Italy. We do not know the results of the mission, but no permanent Italian emporium seems to have been established in Bombay. 
power by the British, he became an accomplice of those who wished to follow the same path, including Italy herself. The Gubernatis who returned to Florence, with his "Indian Museum" in boxes and who published his three volume work, Peregrinazioni Indiane, had reinforced his involvement in the colonial project; his holy and scholarly India was more and more entangled with a commercial-and colonial-India. Gubernatis' India was earlier concerned mostly with the past, studied through history, literature, or linguistics, but by the mid-1880s_coinciding, not by chance, with Italy's growing interest in sharing the European colonial project-his India was also very much involved with the present.

Gerson da Cunha’s frequent trips to Europe, his participation in international conferences, his visits to exhibitions in Paris, and the paper on Dante that he presented in Bombay are but a few examples of an itinerary full of intellectual and cultural references that were not only European or Indian, but which belonged to many Europes and many Indias. The fluidity of his identity was shaped more by what he was not or what he did not do than by his activities or his travels. He was a Goan who lived not in Goa but in Bombay, yet he was neither British nor British Indian; he was of Portuguese nationality (and the Portuguese in India in the sixteenth and seventeenth centuries were one of the main objects of his studies), but he did not live under the rule of the Portuguese government, nor did he visit Portugal on his European journeys; he studied in the British medical schools created in the metropolis to educate doctors from the colonies, but the European country with which he chose to establish intellectual and friendship relationships was Italy, not Portugal or Great Britain. All this invested him the authority of never having been in the position of the colonized.

Gerson da Cunha's dislocation from the place where he was born, the fact of being a "foreigner" in Bombay, came to be determinant in his position as an individual, and in the place from which he could write and produce his own discourse. It was precisely this geographical and identity mobility that enabled Gerson da Cunha to create knowledge on an India that lay at the crossroads between various national, colonial, and local historiographies. He mastered Indian, Portuguese, and British history and historiography, bringing together their many references into a single text. He read and wrote in Portuguese and English and mastered several other languages, both European and Indian. He worked in the archives in Goa, Bombay, Rome, and Paris. He read tombstones in Catholic churches and Sanskrit inscriptions in Hindu temples. He collected objects, especially coins, from many Indias. He was a member of the most prestigious learned 
societies in British India and published, in English, in the best journals, but he was also critical of the "selfish John Bull" and believed that India's liberation was not far off.

Gerson da Cunha was far from being one without a voice or deprived "of language or history," who would appropriate "the language and registry instruments of the colonisers in order to suggest other more heterogeneous histories." ${ }^{61}$ Nor can we argue that Gerson da Cunha took "the voyage in," Edward Said's expression to describe those writers, historians, and intellectuals from the non-European world who made a "conscious effort to enter into the discourse of Europe and the West, to mix with it, transform it, to make it acknowledge marginalized or suppressed or forgotten histories." ${ }^{62}$ Gerson da Cunha presented himself as a historian in the European tradition rather than in the Indian tradition. ${ }^{63}$ Being Goan, though, meant that the language of the colonizers- that is, European culture and historical conceptions-had formed part of his own culture since the sixteenth century, and any division between the European and the nonEuropean is problematic. The idea of appropriation of European culture by the Indian elite living in nineteenth-century British India, so persistent in the English-language historiography, cannot be applied to the case of the Goan scholarly elites.

While enabling him to cross many frontiers, this cultural hybridity embodied within one person could be problematic both for that personas when combining Brahmanism with Catholicism outside the Goan context or when fearing being considered a gentio (gentile) by an Italian readership — and for those who surrounded him, as happened when Gubernatis manifested his difficulty in dealing with what he recognized as the European culture of Gerson da Cunha's family. As a Goan and a Catholic, Gerson da Cunha considered himself closer to the Italian Gubernatis than to the other two, Hindu, Indians who appeared in the photograph. For Gubernatis, though, Gerson da Cunha's sporadic uneasiness with those aspects of his culture that were more associated with non-Christian India was difficult to understand.

61) M. Ribeiro Sanches, "Introdução," on Portugal não é um país pequeno: Contar o império na pós-colonialidade, ed. M. Ribeiro Sanches (Lisbon: Cotovia, 2006): 18.

62) E.W. Said, Culture and Imperialism (London: Chatto \& Windus, 1993): 260-1.

63) J. Gerson da Cunha, "Notes on the History and Antiquities of Chaul," The Journal of the Bombay Branch of the Royal Asiatic Society 33/12 (1876): 51-162. 
Personal letters or handwritten diaries, in private or public archives, such as those used in this article, provide rich and complex examples of cultural encounters and dialogues, but they also are objects that travel between places and cultures. The many texts concerning the photograph-unpublished and published travel journals, newspaper articles, personal correspondence, and museum catalogues-all emphasize the need to view this image in the context of its production, circulation, and reception and to approach it as an inter-cultural object embedded in various kinds of dialogues. It is usually easier to know the various public responses to the same image than the different attitudes of those involved in the production of a photograph, but the story of this photograph brings into question the idea that the multiplicity of meanings derives solely from the reading of an image. It demonstrates instead how instability of meaning can also exist in the context of the photograph-taking and in the intentions of the people who were involved in it. This does not imply that we are stepping back from the image itself or seeking to consider it within a hierarchy dominated by the written word. Rather, we argue for the need to approach the image as an object that is inscribed in a history in which there are other equally meaningful documents. The image is not an illustration of the text. Text and image are interconnected, but one is not a mirror of the other or a different way of saying the same thing. They must be studied together, but without the methodological and disciplinary limitations that can hinder the capture of their relationships and commonalities.

We have seen how this photograph, apart from what and who it represents, has a history as an object travelling between different contexts, between what it could have been and what it became; between the different meanings that it had for different persons; between the different ideas it could suggest in different places of visuality. Both in its making and in its circulation and publication, there were multiple ways of appropriating it, but as important as the meanings that were projected onto it by those who were to be portrayed were the anxieties about how the image would be appropriated by others. The written documents that refer to the photograph are thus rich in "real" dialogues but also in imagined dialogueswhat would our family in Goa say on seeing the photograph of a Catholic family next to Hindus? How would the Italian public see the image in the newspaper?- that were also related to cultural encounters and conflicts. "Dialogue" does not mean an equal participation of its agents in an interchange where all had the right to speak. Some interlocutors could say more 
than others, or, in other cases, would say the same thing but were not listened to as much.

We have also seen how a colonial, national, or ethnic perspective on this image had to be combined with an awareness of other kinds of differences, conflicts, and hierarchies, beyond those inherent in colonial or ethnic inequalities. Within a community that shared the same or a similar knowledge-in this case, knowledge on India-there were other confrontations beyond those that distinguished Europeans from Indians or colonizers from colonized. As we have seen in the published and unpublished dialogues that preceded and followed the making of the photograph, gender, caste, and religion became much more important than ethnicity and nationality as criteria for differentiation and even conflict.

There was a strong consciousness amongst those photographed that the photograph would inevitably unite them in a way that was stronger and more enduring than life itself. Those who finally appeared and those who did not could share the same house, the same food, and even many knowledges, cultural references or friendships, but there was something ultimate and absolute about a photograph that denoted all the identity and cultural differences that existed but had not been mentioned. The idea of unification, inseparable from a photograph's power of two-dimensional representation, became latent in the final criteria that defined those who should be there: what united them, not what separated them, was their common knowledge of the languages, literatures, and cultures of India.

Both the image, which was published in a popular Italian newspaper, and the nineteenth-century manuscript letters and travel diary that refer to it are in Italy, therefore, in a nation that is not central to the historiography that concentrates on nineteenth-century colonialism. A recent nation, it was only with her unification that Italy began to be seriously interested in following other European countries' colonial paths. Its history, however, is also embedded in the context of British colonial India, a colonial context with no direct link to Italy. As an example of a globalized visual culture in which both the people being studied and the photograph that brought them together resist precise identification, such an image would never have been found in the historiographical approaches that remain within the relationships between metropolis and colonies, in this case Great Britain and British India, and Portugal and Portuguese India or in a nationcentred approach to colonial India. The problems this photograph raisedthrough both the image itself and the wider context of the production of knowledge on India in Florence or Bombay—suggest how a transnational 
approach to non-European spaces that were also colonies can accord better with the mobility and circulation of knowledge itself and the multiple forms of cultural encounters and dialogues between different historical agents, both in and outside of colonial contexts.

\section{Bibliography}

BNCF Biblioteca Nazionale Centrale Firenze (Central National Library of Florence)

Abstract of the Society's Proceedings. 1885. The Journal of the Bombay Branch of the Royal Asiatic Society 43: xxvi-xxxiii.

Burton, Isabel. 1879. AEI: Arabia, Egypt, India: A Narrative of Travel. London: William Mullan and Son.

Catalogo del Museo Indiano. 1887. Florence: Le Monnier.

Cohn, Bernard S. 1996. Colonialism and Its Forms of Knowledge: The British in India. Princeton: Princeton University Press.

Correspondence Angelo de Gubernatis, Letter from José Gerson da Cunha, 16 (Hornby Road, Bombay, 17 March 1879). MS. BNCF.

- Letter from José Gerson da Cunha, 39 (Hornby Road, Bombay, 5 November 1885). MS. BNCF.

. Letter from José Gerson da Cunha, 44 (39 Hornby Road, Bombay, 13 July 1886). MS. BNCF.

- Box 154, letter from Pramod Kumar Tagore (Calcutta, Pathuria Ghata Raj Bati, 18 November 1886). MS. BNCF.

—. Box 154, letter from Pedro d'Alcântara (Rio de Janeiro, 5 October 1886). MS. BNCF.

Cunha, José Gerson da. 1876. Notes on the History and Antiquities of Chaul. The Journal of the Bombay Branch of the Royal Asiatic Society 33/12: 51-162.

- 1881. Materials for the History of Oriental Studies Amongst the Portuguese. In Atti del IV Congresso Internazionale degli Orientalisti tenuto in Firenze nel Settembre 1878. Florence: Le Monnier: 2: 179-219.

- 1925. Francisco Caetano da Cunha e sua família. Nova Goa: Tip. da Casa LusoFrancesa. (Family book made of two different parts: a biographical sketch of Francisco Caetano da Cunha written in 1870, followed by an In Memoriam dedicated to José Gerson da Cunha, compiled by his brother António Maria da Cunha.)

De Cara, Cesare A. 1883. Errori mitologici del professore Angelo de Gubernatis. Prato: Tipografia Giachetti.

De Gubernatis Brahmino. 1885. L'Illustrazione Italiana 12/50: 378-80.

Dehejia, Vidya, ed. 2000. India through the Lens: Photography 1840-1911. Washington DC: Smithsonian Institution.

Desmond, Ray. 1982. Victorian India in Focus: A Selection of Early Photographs from the Collection in the India Office Library and Records. London: HMSO.

Dharamsey, Virchand. 2012. Bhagwanlal Indraji: The First Indian Archaeologist. Multidisciplinary approaches to the past. Vadodara: Darshak Itihas Nidhi. 
Dodson, Michael S. 2007. Orientalism, Empire and National Culture: India, 1770-1880. Basingstoke: Palgrave Macmillan.

Edwards, Elizabeth, ed. 1992. Anthropology and Photography, 1860-1920. New Haven: Yale University Press.

Falconer, John. 1990. Photography in Nineteenth-century India. In The Raj: India and the British, 1600-1947, ed. C.A. Bayly. London: National Portrait Gallery.

_ , ed. 2001. India: Pioneering Photographers 1850-1900. Exhibition Catalogue. Brunei Gallery SOAS. London: The British Library.

— 2002. "A Pure Labor of Love": A Publishing History of The People of India. In Colonialist Photography: Imag(in)ing Race and Place, ed. Eleanor M. Hight and Gary D. Sampson. London: Routledge.

Geertz, Clifford. 1973. Thick Description: Toward an Interpretive Theory of Culture. In The Interpretation of Cultures: Selected Essays. New York: Basic Books: 3-30.

Gracias, João B. Amâncio. 1901. Notícia necrológica e biográfica de Gerson da Cunha. $O$ Instituto: 48/1: 479.

Gubernatis, Angelo De. 1885. Un italiano in India: Bombay, 14 Ottobre. La Nazione, 6 Nov.: 2.

- 1885-6. Relazioni del suo viaggio nell'India, autogr. MS [II, IV, 674], BNCF.

- 1886. Peregrinazioni indiane, vol. 1, India centrale. Florence: L. Niccolai.

- 1887. Peregrinazioni Indiane, vol. 2, India meridionale e Seilan. Florence: L. Niccolai.

- 1900. Fibra: Pagine di ricordi. Rome: Forzani.

Guha-Thakurta, Tapati. 2004. Monuments, objects, histories: Institutions of art in colonial and postcolonial India. New York: Columbia University Press.

Gutman, Judith Mara. 1982. Through Indian Eyes: 19th and 20th Century Photography from India. New York: Oxford University Press.

Hight, Eleanor M., and Gary D. Sampson. 2002. Introduction: Photography, "Race," and Post-colonial Theory. In Colonialist Photography: Imag(in)ing Race and Place, ed. Eleanor M. Hight and Gary D. Sampson. London: Routledge: 1-19.

Inden, Ronald. 2000. Imagining India. London: Hurst.

The Indian National Congress 1885-1985: An Exhibition in the British Library to Mark the Centenary of the First Meeting of the Indian National Congress at Bombay in December 1885 (30 November 1985-February 1986). 1985. London: British Library.

Jacobson, Ken. 2007. Odalisques and Arabesques: Orientalist Photography 1839-1925. London: Quaritch.

The Kama Sutra of Vatsyayana, Translated from the Sanskrit. 1883. Cosmopoli: Kama Shastra Society of London and Benares.

The Kama Sutra of Vatsyayana. 1990. Trans. Richard Burton and F.F. Arbuthnot, ed. W.G. Archer. London: Guild.

Karlekar, Malavika. 2005. Re-visioning the Past: Early Photography in Bengal 1875-1915. New Delhi: Oxford University Press.

Kennedy, Dane. 2005. The Highly Civilized Man: Richard Burton and the Victorian World. Cambridge MA: Harvard University Press.

Lovell, Mary S. 1998. A Rage to Live: A Biography of Richard and Isabel Burton. London: Abacus.

McConnachie, James. 2007. The Book of Love: In Search of the Kamasutra. London: Atlantic. 
Moraes, George Mark. 1967. Dr. José Gerson da Cunha, 1844-1900. Memorial Volume. Journal of the Asiatic Society of Bombay. (1964-5) 39-45.

Pelizzari, Maria Antonella. 2003. Introduction. In Traces of India: Photography, Architecture, and the Politics of Representation, 1850-1900, ed. Maria Antonella Pelizzari. New Haven: Yale University Press: 13-8.

—, ed. 2003. Traces of India: Photography, Architecture, and the Politics of Representation, 1850-1900. New Haven: Yale University Press.

Perez, Rosa Maria, Susana Sardo, and Joaquim Pais de Brito, eds. 1997. Stories of Goa. Exhibition Catalogue. Lisbon: Museu Nacional de Etnologia.

Pinney, Christopher. 2008. The Coming of Photography in India. London: The British Library. - 1997. Camera Indica: The Social Life of Indian Photographs. London: Reaktion.

Report of the First Indian National Congress Held at Bombay on the 28th, 29th and 30th December 1885. 1885. Lucknow: G.P. Varma \& Brothers.

Roberts, Mary. 2007. Intimate Outsiders: The Harem in Ottoman and Orientalist Art and Travel Literature. Durham: Duke University Press.

Ryan, James R. 1997. Picturing Empire: Photography and the Visualization of the British Empire. London: Reaktion.

Said, Edward W. 1978. Orientalism. London: Routledge and Kegan Paul. 1993. Culture and Imperialism. London: Chatto and Windus.

Sanches, Manuela Ribeiro. 2006. Introdução. In Portugal não é um país pequeno: Contar o império na pós-colonialidade, ed. Manuela Ribeiro Sanches. Lisbon: Cotovia.

Schwartz, Joan M., and James R. Ryan, eds. 2003. Picturing Place and the Geographical Imagination. London: I.B. Tauris.

Tagg, John. 1988. The Burden of Representation: Essays on Photographies and Histories. London: Macmillan.

Tapati Guha-Thakurta, Monuments, Objects, Histories. Institutions of Art in Colonial and Postcolonial India (New York: Columbia University Press, 2004).

Thomas, Nicholas. 1994. Colonialism's Culture: Anthropology, Travel and Government. Princeton: Princeton University Press.

Tromans, Nicholas, ed. 2008. The Lure of the Orient: British Orientalist Painting. London: Tate.

Vicente, Filipa Lowndes. 2009. Outros Orientalismos. A Índia entre Florença e Bombaim 1860-1900. Lisbon: Imprensa de Ciências Sociais.

- 2010a. "The Goan historian José Gerson da Cunha at the Bombay Branch of the Royal Asiatic Society (1870-1900), Journal of the Asiatic Society of Mumbai (Mumbai: The Asiatic Society of Mumbai), vol. 83, 2009-10, pp. 128-136.

—. 2010b. "Orientalismos periféricos? O historiador goês José Gerson da Cunha (Bombaim, 1878)”. Ler História, 58, pp. 27-46

- 2010c. "Orientalism in the margins. The interest in Indian Antiquity in nineteenth century Italy", in Res Antiquitatis. Journal of Ancient History, Vol. 1, 11-37.

—. 2005a. "O S. Francisco Xavier de Isabel Burton e de Mrs. Guthrie: duas inglesas em Goa na década de 1870”, Oriente, nº13 (Dezembro), pp. 70-109.

—. 2005b. "A Arte sem História. Mulheres Artistas (Séculos XVI-XVII), Artis. Revista do Instituto de História da Arte da Faculdade de Letras de Lisboa, no 4, pp. 205-242.

—. 2004. "Exposiçóes coloniais na Índia portuguesa e na Índia britânica (séculos XIX e XX)", Oriente, no 8 (April), pp. 70-88. 
-Viagens e Exposiçôes: D. Pedro V na Europa do Século XIX [Travels and Exhibitions: D. Pedro V in 19th century Europe] (Lisboa: Gótica, 2003).

Visram, Rozina. 2002. Asians in Britain: 400 Years of History. London: Pluto.

Wagoner, Phillip B. 2003. Pre-colonial Intellectuals and the Production of Colonial Knowledge. Comparative Studies in Society and History 45/4: 783-814.

Xavier, Ângela Barreto. 2005. David contra Golias na Goa seiscentista e setecentista. Escrita identitária e colonização interna. Ler História 49: 107-43.

Yajnik, Indulal. 1950. Shyamaji Krishnavarma: Life and Times of an Indian Revolutionary. Bombay: Lakshmi.

Županov, Ines G. 1999. Disputed Mission. Jesuit Experiments and Brahmanical Knowledge in Seventeenth-century India. New Delhi: Oxford University Press. 